International Journal of Linguistics, Literature and Translation

ISSN: 2617-0299 (Online); ISSN: 2708-0099 (Print)

DOI: 10.32996/ijltt

Journal Homepage: www.al-kindipublisher.com/index.php/ijltt

\title{
Authoritative Structures of British Feminist Colonial Discourse: Emily Keen's Travel Narrative My Life Story as a Case Study
}

\author{
Dr. Iman Raissouni 8 (iD) \\ Associate Professor, Abdelmalek Essaadi University, King Fahd School of Translation, Tangier, Morocco \\ $\triangle$ Corresponding Author: Dr. Iman Raissouni, E-mail: imraissouni@uae.ac.ma
}

\author{
ARTICLE INFORMATION \\ Received: May 11, 2021 \\ Accepted: June 08, 2021 \\ Volume: 4 \\ Issue: 6 \\ DOI: $10.32996 /$ ijllt.2021.4.6.4
}

\section{KEYWORDS}

Travel writing, East-West

encounters, representation,

colonial Morocco

\section{ABSTRACT}

This paper analyses the representation of Morocco by a British female traveller during the late nineteenth and early twentieth century. Emily Keen's My Life Story attempts to set out the conditions in which women travelled and translated the reception of their experiences into autobiographies in their native countries, breaking down the boundaries of space and time to discover and interpret the discourse that traverses the writer's narrative. The endeavour is to show how what was imagined about the country, what was a fantastic legend about Morocco, what started as an innocent story and literary entertainment for British readers, built up to make an authoritative discourse of colonisation. My intention and method go so far as to broaden the range of issues connected to travel writing. These issues include gender, race, identity, and personal experience, etc. Through this lens, I argue that such writers were conscious and unconscious informants preparing the way for the European colonisation of the country; they are the living witnesses of an evolution through which a culture was forced to open itself to foreign powers.

\section{Introduction}

The long history of encounters between Western and Eastern civilizations produced a tradition of portraying the Eastern nations and cultures. There has been a clear understanding that Western writers interpret and analyse instances of their encounters with subordinate cultures in their writing practices in light of power as a social construct, using ideology, hegemony and discourse as key concepts to explain the intersections between the social production of knowledge and the perpetuation of power relations.

The colonial archive is loaded with a variety of writings accounting for the interplay between the West and its opposite 'Other'. Colonial and postcolonial accounts of the West's relation to the rest of the world tend to place much stress on the importance of travel writing as a watershed that reveals how Western intellectual travellers have widely examined and portrayed other peoples in their chronicles. This work began with Edward Said's book Orientalism (1978) which traced the similarities in the rhetorical and informational structure of a wide range of seemingly objective writings about the Orient. For him, travel writing is essentially an instrument within the colonial expansion and serves to reinforce colonial rule once in place. Of paramount importance in this connection is Michael Foucault's book The Archaeology of Knowledge (1969) and Mary Louise Pratt's book Imperial Eyes: Travel Writing and Transculturation (1994), which have been widely devoted to reflecting the inherent conflict involved in constructing networks of power through knowledge.

Building upon a bunch of discourse theories, this paper is an attempt to bring at issue a feminist critical reading strategy to unveil the authoritative structures of Western colonial discourse and determine the degree of reliability, authenticity, and interpretative capacity of its textual manifestations. Such endeavour to explore the world of colonial texts opens up a number of questions pertaining to the fashion in which discourse theorists construct intellectual contexts through such defining terms as "accounts of travel", "displacement", or "Diasporic experiences" (Kaplan 1996, p. 5), and raises issues of how the feminist

\begin{tabular}{lll|l} 
K & C & AL-KINDI CENTER \\
$\mathbf{R}$ & $\mathbf{D}$ & FOR RESEARCH AN
\end{tabular} $\mathbf{R}$ D FEVELOPMENT Your gateway to world-class research

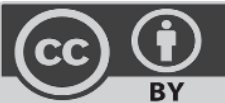

Published by Al-Kindi Center for Research and Development, London, United Kingdom. Copyright (c) the author(s). This open access article is distributed under a Creative Commons Attribution (CC-BY) 4.0 license 
discourse produced within the colonial space confines the societies, traditions, and identities of the Oriental subject within certain latent and manifest geopolitical parameters?

Exploring Western discourse brings to mind several inquiries as to what extent have historical accounts on this encounter successfully reflected mere realities and indiscriminate facts on previously colonized cultures by their colonizing 'Other'? What are the differences of discursive frameworks in entailing reading strategies about other cultures and peoples? Has the knowledge produced during this encounter been heterogeneous or unitary?

My argument in this research paper emanates from my observation that most travel chronicles tend to reflect the personal experiences of their authors more than mere facts and realities. This is why there has been a need to understand the ways in which migrants or travellers construct imagined and local communities in order to be able to define the common rhetoric between their different versions, locating their narratives within larger structures of both material and symbolic power to stress the importance of the articulations of travel and gender within travel culture. It is also interesting to see how one can take wellknown female accounts and read them not as eccentric products but as part of a broader discourse about gender, colonialism, and travel experience.

\section{Colonial and post-colonial theoretical perspectives 2. 1. Post-colonial discourses of displacement}

A major feature of post-colonial literatures is the concern with place and displacement. The dialectic of place and displacement is always a feature of post-colonial societies, whether a process of settlement, the intervention has created these or a mixture of the two. Beyond their historical and cultural differences, place, displacement, and a pervasive concern with the myths of identity and authenticity are features common to all post-colonial literature in English. Most bodies of modern critical work have centred on certain travel terms ${ }^{2}$ such as location and dislocation, placement and displacement, dwelling and travel without inquiring into the possibility for such terms to create symbols or metaphors representing key differences of power between nationalities and genders. Thus, the striking question that calls one's attention is: what is the ideological function of these constructions in the discourse of displacement? is it simply to create amalgams about the imagined 'Other'? or are they meant to reflect an account of subordinate peoples and their lives?

Caren Kaplan in her book Questions of Travel: Postmodern Discourses of Displacement, explicitly articulates her stand towards Euro-American discourses of displacement, stressing their political implications. Thus, she argues: "Euro-American discourses of displacement tend to absorb the difference and create ahistorical amalgams; thus a field of social forces becomes represented as a personal experience, its lived intensity of separation marking a link with others." (Kaplan 1996, p. 2). Instead of serving as historical documents for the perception and reception of different social and critical practices, Euro-American discourses of displacement turn these practices into personal experiences portraying mystifications and often ahistorical universalisations about the constructed, imagined 'Other'. Those discourses and disciplines produce a certain kind of knowledge mystified enough to create imagined textual practices.

Colonial writing practices tend to be Eurocentric in nature. As is asserted by Pushkala Prasad in Crafting Qualitative Research (2005), "One of the main problems of Eurocentrism lies in its blindness about the flaws and limitations of Western culture, while simultaneously being unable to recognize the strengths and contributions of non-Western cultures. [. . .], Eurocentrism sanitizes Western history while simultaneously demonizing or patronizing the non-West." Not only does Eurocentrism reproduce colonial ideologies, but it also normalizes many hierarchies such as Orient/Occident and civilized/primitive. This is the reason why discourse is said to have complicity with power as it manifests itself in the realm of domination and counter-domination.

In her description of Eurocentric colonial critical practices in theories of displacement, Kaplan further perceives what she calls 'politics of location' used by Western intellectuals in handling the colonial 'Other'; she deems this practice to be an essentialist Western identity politics. She asserts that this politics of location, given its contradictory uses and dimensions, can only be relevant if utilised to "[. . .] destabilize unexamined or stereotypical images that are vestiges of colonial discourse and other manifestations of modernity's structural inequalities [. . .]" (Kaplan 1996, p. 139). Western intellectuals, in this sense, should take a clear stance with regards colonialism; they should mark prejudiced accounts about the constructed 'Other' and signal the formation of Diaspora identities instead of destabilizing people and framing them as subordinate.

\footnotetext{
${ }^{2}$ For Kaplan, travel terms such as displacement, location, or dwelling give rise to certain travel symbols and metaphors to come into play. These travel symbols may be misleading because they are loaded with diverse contradictory meanings about competing cultures and nations. Such a liberal nature of these travel metaphors allows for the possibility of creating conflicts between different societies and nationalities. (see the introduction of Kaplan's Questions of Travel: Postmodern Discourses of Displacement)
} 
Thus, Fraser \& Nicholson (as cited in Kaplan, 1996, p. 17), suggest a "non-universalist" and "pragmatic" critical theoretical practice that "'would be attuned to the cultural specificity of different societies and periods [and]. . . would tailor its methods and categories to the specific task at hand, using multiple categories when appropriate, avoiding single or total methods and epistemologies." The suggested framework falls within the idealist mode of critical representation because it is meant to suit different kinds of culture - both local and global - different periods of time, various colonial spaces, and different progressive political changes. Hence, it is a revolutionary attitude against all forms of Eurocentrism apparent in Western colonial writings.

\section{2. Feminist politics of Location}

Colonial discourse theory has recently been an almost exclusively patriarchal domain of agency; women's travel writing has long been considered the genre of second-rate writers, which gave rise to a new discourse of feminist critics who attempted to deconstruct dominant hierarchies and sweep away all old prejudices and hegemonic uses of the term 'gender'.

Given the fact that gender issues are conceived as wholly limited to the masculine sex, Simone De Beauvoir states that there is also room for feminist identity politics: "The category of gender identity was not determined by one's biological sex; rather gender is a social construct, which can be resisted through social and political struggle." (1973, p. 301). Following de Beauvoir's perspective, it is the society which constructs the relationship of different sexes and assigns each one a certain position in it, hence associating the female gender with weakness while simultaneously granting the male gender power and supremacy. This reflects the power of social institutions in constructing and determining the parameters of power and the limitations of gender identity.

Inspired by De Beauvoir's perspective on feminist critical theory and gender identity, Gayatri Chakravorty Spivak asserts her social and intellectual identity by examining the limits of - emphatically - Western feminist discourse and its failure to account for the third world disempowered women. Thus, in her essay "Three Women's Texts and a Critique of Imperialism", Spivak observes that ". . . what gets left out of such accounts [Western feminist travel accounts] is the historical role played by the nonwestern woman in this narrative of empowerment." (Spivak, 1997, p. 145). Reactionary as it may be, Spivak addresses the strategies followed by Western feminist intellectuals in the production of critical social formations and highlights the epistemic violence of imperialism in elucidating deconstructions of the historically-muted native subjects, or what she labels the 'subaltern', referring to disempowered women from third world societies, mainly India and Asia. Colonized or third world women were always marginalized in the Western critical process of carving out historical and political events; this is further elaborated in Spivak's realization of "[. . .] the ethnocentrism of Western feminism and its complicity in the regimes of (neo)-colonial knowledge, [. . .]" (Spivak, 1997, p.145), what marks the continuation of the neo-colonial and imperial projects not only in territorial or economic forms, but also in textual ones.

Yet, Spivak shifts her focus from de Beauvoir's social issues such as gender identity and sexual difference into broader colonial and cultural levels such as the difference between third world and first world women and manifestations of subjugation in the colonial theorizations of subordinate cultures. Always cutting-edge and controversial, Spivak champions the voices and texts of the colonized which were marginalized by Western culture. She also criticizes Western feminism for the claim that it speaks for and represents all women. (Cited in Morton 2003, pp. 71-72) The case of 'Jashoda', the fictional third world woman in Mahasweta Devi's "Breast Giver"3, is an illustration of the seclusion strategies followed by Western feminists. 'Jashoda' is employed as a "professional mother" who nourishes the Brahmin family with her breast milk; the constant exploitation of Jashoda's maternal body caused her a breast cancer which resulted in her death. (Morton 2003, p. 76). In Devi's "Breast Giver", thus, the portrayal of 'Jashoda' as a third world disempowered subject focuses on her function as a domestic woman-worker while her value as a human subject is overlooked. This reasserts Spivak's assumption that Western feminist discourse is shaped by imperial vicissitudes; 'Jashoda's case challenges the claim that Western feminism is concerned with the social problems of all women in the globe by pointing to the drawbacks of feminist writing traditions with regards to the representation of women workers.

In her article "Can the Subaltern Speak?" (cited in Nelson and Grossberg, 1988), Spivak further inquires into the possibility of restoring the feminist native voice that was muted in the context of Western feminist discourse; excluding the subaltern or muted groups of society from colonial feminist discourse pushed third world disempowered women to react against their marginalisation. Ironical though it may be, subaltern third world women reacted against their suppression by the colonial agent, asserting themselves by functioning as "native informants" to the colonizer. On the one hand, this reactionary native strategy is the only way for muted subjects to show up their lost identity and preserve themselves from suppression and annihilation, but, on the other hand, it serves the hegemonic imperialist and capitalist standard projects of monopolizing the "Oriental" subjects and territories. A close examination of Spivak's 'native informant' is found in the following excerpt which analyses Spivak's $A$ Critic of Postcolonial Reason: Toward a History of the Vanishing Present as follows:

\footnotetext{
${ }^{3}$ Mahasweta Devi's "Breast Giver" is an article found in Breast Stories translated by Gayatri Chakravorty Spivak from Indian into English language.
} 
In the tight methodological program sketched by the four chapters of her book, this discipline of 'the other', so to speak, is only one of the many fields held up to her methodology. It is not a crucial one either, because there, the native informant is exploited, mistrusted, altered perhaps, but not suppressed. Instead, Spivak's native informant is a figure, a figuration put forward to counter the unfortunate effects of contemporary flirtations with those universalized, idealized, and thereby offensively misused figures of the 'other' - the 'nomad' or the 'migrant' (Bal $\&$ Macdonald 2002, p. 297).

Spivak employs the term "native informant" as a strategic variable in reflecting the effects of colonization on the lives of disempowered women in third world nations through stressing the fact that the suppression of the subaltern's voice resulted in rebellion from the part of muted colonized subjects.

The party which sanctions the writing uses the "native informant" to help it in the writing of historical narratives. The stories that the latter provides are taken possession of being denied autobiography. The imaginative figure of the native informant thus becomes a site of unlisted traces and the writer realizes this by not admitting the source of information and by calling him a man in general (Spivak 1999, p. 5). In this sense, the native informant is always seen as an exotic, strange, and vague 'Other', which is further emphasized by Maggio when he said: "The native informant is always existing on the margins, and hence not existing at all. Its definition is its erasure: the distance between its two worlds of representation is turned into a "persisted disruption"" (Maggio 2007, p. 421). The disrupted vision that the native informant produces cannot be guaranteed by the colonial agent to be authentic and trustworthy. Thus, though the native subaltern reacted against her identity-suppression by the colonizer by acting as a native informant, she was justifiably not successful in liberating herself from the belts of marginality and passivity originally attributed to her character.

Sara Mills, (cited in Pratt 1994, p. 30) also touches on the idea that knowledge produced within the imperial context is extremely heterogeneous, but she remarkably relates this knowledge to the issue of gender. In this context, Mills states: '“[. . .], I am asserting that gender always makes a difference, particularly within the imperial context that is produced as a profoundly gendered environment."'(Pratt 1994, p. 30). The difference that characterizes colonial discourse is related to 'gender'; hence, writing traditions tend to differ according to the gender of their authors. This is explicitly revealed in the following excerpt, asserting that:

[. . .], women's writings and their involvement in colonialism was markedly different from men's; their work was informed by different discursive frameworks and pressures. [. . .]. Because of the way that discourses of femininity circulated within the late nineteenth and early twentieth centuries, women travel writers were unable to adopt the imperialist voice with the ease with which male writers did (Mills 1993, p. 3)

The difference between male and female discourses within the imperial context is further demonstrated by Mills, who points to the way gender structures texts in both their production and reception. Colonial discourses are characterized by subversion and heterogeneity because they get influenced by the gender of their authors; thus, texts no longer provide a unitary knowledge because they are the output of various interactions and struggles, once between the male and female genders, and often between subordinate and powerful structures.

\section{Engendering Difference in Western Discourse}

Building on the Orientalist tradition created and adopted by the West, a peculiar tradition of Eurocentric writing has emerged, historicizing the supremacy of the West over its 'Other' through the systematic creation of a discourse of difference and racial classification. Questions of domination, hegemony, and identity politics have been central in this type of hegemonic discourse that manages to denude the humanity of other cultures and fix them within the Oriental make-up, which has since been reflected as a model in which Europe's strategies for knowing the non-Western world became strategies for dominating that world.

Theories in colonial discourse have identified the enormous significance of travel writing as an ideological apparatus of Empire; writing other cultures produces texts as symptoms of imperial ideologies that reveal a prejudiced knowledge about the 'Other' overlain with repetition and unreality. They are, therefore, a way of introducing concepts of cultural difference and discussing the way in which writing does, or does not shape perceptions. In this context, it is noteworthy to discuss the ways in which difference in Western discourse is construed, and to what extent it contributes to producing heterogeneous and divergent discourses. Hence, how are the images that represent a difference in culture elaborated to classify and locate the East in the realm of Otherness? What are the issues and problems that such representations create?

Mary Louise Pratt is aware of the imperial meaning-making strategies used by European travel writers in envisioning subordinate cultures. This is explicitly revealed when she enquires about 
how travel books by Europeans about non-European parts of the world went (and go) about creating the "domestic subject" of Euro-imperialism; how they have engaged metropolitan reading publics with (or to) expansionist enterprises whose material benefits accrued mainly to the very few (Pratt 1994, p. 4)

At this juncture, the imperial endeavours of Western writings are conveyed as to dismantle the sovereignty of other cultures by emphasizing the need for Western expansionism, which is an old Euro-imperialist rhetoric of conquest permitted by the defining terms of 'power' and 'authority'.

While emphasizing the Eurocentrism of Western discourse strategies, Pratt also demonstrates that those writing strategies are a result of writing in what she called 'a contact zone', a term coined in Pratt (1999) to refer to "social spaces where cultures meet, clash, and grapple with each other, often in contexts of highly asymmetrical relations of power, such as colonialism, slavery, or their aftermaths as they are lived out in many parts of the world today." (Pratt 1999, p. 519). Pratt emphasizes the irregularity in the two cultural positions and the ensuing struggle to recognize and understand the other and the self. Thus, by using the term 'contact zone', Pratt seeks to examine each encounter on its own terms, since it entails the active intermingling of two or more cultures in any social colonial or postcolonial spaces in which one group dominates the other.

The interaction of two different cultures in the same social space creates various writing strategies. In Pratt's "Arts of the Contact Zone" and Imperial Eyes, two writing traditions are presented as being the arts of the contact zone. These two traditions are labelled by Pratt as auto ethnography and transculturation, respectively. While auto ethnography refers to a group of people writing their own culture that other people from other cultures have already written (Pratt 1999), transculturation refers to the way marginal groups of society adopt certain criteria or qualities from the more dominant group and apply them in their writings while still preserving their own identity and heritage (Pratt 1994, p. 523). Drawing upon these examples, Pratt constitutes a way that combines the ideas and attitudes of different cultures through a selective collaboration with and appropriation of idioms of the invaders together with indigenous idioms to create valuable self-representations.

As regards Western travel writings on non-Western cultures, Pratt divides them into two types, each with its own narrative figures: the 'manners and customs' figure, and the 'sentimental' figure. While the first figure is highly impersonal, using generalising statements beyond the speaking 'I' of the narrator, the second tends to foreground the narrator's voice (Pratt 1985, p. 126). In her analysis of the 'manners and customs' figure, Pratt realizes that those generalising statements essentially emanate from the framework of knowledge and power which travel writers, instigated by the colonial machinery, attempt to normalise. Representing negative accounts about other nations is common currency in Western travel writing of the 'manners and customs' type. Pratt manages to trace the reason behind such accounts, which, as she emphasizes, are meant "to reduce current ... societies to vestiges of a glorious past." (Pratt 1985, p. 126). On the other hand, in her analysis of the 'sentimental' figure, Pratt reveals the cooperative process between the narrator and indigenous individuals usually represented in dialogues or conversations. This second type of Pratt's figures seems to be more personal than the previous type; it gains authority from the fact that it is concerned with people as individuals. Thus, the two modes of travellers analysed by Pratt involve structures of authority, personal as well as colonial.

\section{Mapping identities in a British female travel narrative on Morocco 4.1. Representing the 'Other' in the Colonial Space}

Most scholars generally tend to exclude or marginalize the roles played by Western women in colonial history by simultaneously stressing the masculine nature of cultural and colonial theories (Mills 1993, p. 27). The result of this tendency toward masculine patriarchy is the practicing of travel writing by women, whose revolution against male centeredness affords them legitimacy and access to authority through knowledge. From this point, the concern is drawn to the travel tales of women who first transformed themselves into travellers and then transformed their travels into autobiographical, political, and cultural occasions. In this context, autobiographies written at the turn of the century are important for their interrogation of the category of the woman in the making of self-consciousness and self-authorization. In identifying the common strategies employed by self-representation, and in contextualizing self-writing within the broader framework of the nineteenth and twentieth-century trends, this analysis demonstrates how this text reinforces the hierarchies of imperialism while staking out a place within political or cultural traditions.

Emily Keene's My Life Story is an attempt to set out the conditions in which women travelled and translated the reception of their experiences into autobiographies in their native countries. While Keene appears to describe, emphatically, the Moroccan characters and manners through her writings, she simultaneously also seeks to establish subjective discourses about the 'Other'. 4 This leads us to enquire into the possibility for female writers to assert Western agency and authority by way of autobiographical

\footnotetext{
${ }^{4}$ The 'Other' in this context is taken not simply to refer to different individual figures but by extension to different cultures and geographical spaces.
} 
representation. In Keene's case, such process of investigation leads to the following questions: How does Keene as a woman writer use self-representation and its constitutive possibilities for agency and subjectivity to become subject instead of the object for the subjectivity of self-representational agency? In other words, in what ways does her self-representation occur and what are the cultural and political constitutions and forms in relation to which it is written? Was her text successful in reflecting the truth about the journeys she undertook or was it a politicization of identity construction? In this case, Self-representation and authority get linked up together with projects that encode power identity. There are a variety of discourses and practices that converge in autobiography to depict the individual in relation to the truth, the real, and identity. Hence, autobiography is about striving to produce the truth, and it is the task of cultures to code this truth production through discourses that can be judged as truthful or imaginary.

Truth and knowledge production are always blurred by political endeavours. As Foucault articulates: "For the least glimmer of truth is conditioned by politics." (Foucault, 1979, p. 5). One may then position truth within the realm of authority and power relations that structure any cultural discursive representation. Through the analysis of confession and truth-telling, the examination of the limits of human agency toward colonial agency in truth production is further articulated by Keene when she states: "Everything in Morocco is deteriorating, and lamentations for the good old times are heard from every section of the people, no matter what their station in life." (Keene, 1912, p. 60). It is clearly in this sense structured by colonial discourse in that one of the ways in which travellers support the colonialist venture is in describing the political changes taking place, thus legitimizing the necessity for the colonial relation between Europe and Morocco.

The quest for colonial agency is made apparent in the context of the comparison between Morocco and Algeria, on which Keene reflects: "In the summer of 1907, I promised to join Muley Ali [her son], then in Algeria, to enable my two little grandsons to see some civilised town, and to travel over the railway." (Keene 1912, p. 161). Keene's discussion of Algeria in this context is a trope into marking the difference between two contingent Muslim parts, inserting implicitly the backwardness of the Moroccan land which still struggles against colonial interference while reflecting the civilisation of the Algerian one which is already colonized by the French and hence, supposedly, civilized. This amounts to the power of autobiographies in legitimizing the colonial enterprise through associating the colonial occupation with the civilizing mission. Thus, female travellers are then observed to provide endorsements of Empire and accounts of personal experience that undercut it.

Keene is then observed to be representative of the colonial power; she did not have authority only from this source, but her account is directly drawn upon by the colonial powers. The missionary nature of Keene's residence in Morocco is asserted towards the end of the book when she says: "Today 50 per cent of the population will consult a medical man or lady, and here the good work of the missionaries is most noticeable" (Keene 1912, p. 156). The declared agenda of Keene's missionary travels illustrates one of the double-facets of self-representation which, in this specific context, is complicit in the reinforcement of imperial and colonial hierarchies. Keene's very mobility in the colonial space produces different interpretations of her writings. Using her authority as a domestic agent ${ }^{5}$, Keene intervenes in imperial discourse. In this textual intervention, she is drawn again and again to discussions of the Others' indulgences and daily practices.

Instances supporting the premise that Keene's representation of the 'Other' is mediated by discourses of authority are revealed throughout her chronicle. Observing the differences between Moroccan and British customs, Keene, in her account of Moorish ceremonies, states: "The first time I saw a Moorish baby in this rig-out I was horrified and longed to take it out and make it comfortable according to my ideas ..." (Keene 1912, p. 13), hence asserting the difference and illegibility of the Moroccan mentality to the European consciousness, and at the same time the latter's superiority. Within the same realm, Keene is attentive to reflect the difference, in terms of character, between Moroccans and Europeans, which she labels as follows: "The Moors' ideas, manners, and customs cause them to gauge affairs so differently to ours; their imagination is of the wildest, and they rush to conclusions before they have fully realised the subject in hand. The Shareef [of Wazan] was but little different from the generality of his co-religionists." (Keene 1912, p. 130). So it is apparent how Keene's recording of her comments and impressions on Morocco plays a significant role in inspiring a great number of attitudes, judgements, and prejudices the British have toward Moroccans throughout history.

\subsection{Self-representation in the colonial space}

Self-representation or what is today called autobiographical practices are both an articulation of women's life experiences and a source for articulating feminist theory; life stories told by women about themselves stretch the truth to be worthy of critical investigation. In this context, autobiographies written at the turn of the century are important for their interrogation of the category of a woman in the making of self-consciousness and self-authorization. In identifying the common strategies employed by self-representation, and in contextualizing self-writing within the broader framework of the nineteenth and twentieth-century

\footnotetext{
${ }^{5}$ The word 'domestic' in this context refers to Keene's nurseries in Morocco in the Pre-Protectorate period.
} 
trends, this analysis demonstrates how feminist texts tend to not only reinforce but also challenge the hierarchies of imperialism while staking out a place within political, cultural and social traditions.

The approach to women's autobiography tends to be based on experiential models and foregrounds certain moments in the life cycle, such as: childhood, adolescence, marriage, giving birth . . . etc. This is clearly reflected in Keene's account of the ceremonies associated with giving birth in Moroccan culture:

The name is given to a Moslem child on the eighth day of its birth, though I believe the seventh is the right date. On the morning of the ceremony a large ram is sacrificed, and this is generally slaughtered by a near relative, who pronounces the child's name when cutting the animal's throat in the presence of invited guests.(Keene 1912, p. 19)

As is apparent, Keene here provides new insights into travel writing tradition because she does not follow the Orientalist fashion of denuding and undermining other cultures; instead, she provides an account of the country, its people and customs while at the same time describes her experience with them as a non-native female.

Western female travel writers conceive of themselves as remarkable, exceptional, and eccentric women who somehow managed to escape the structures of patriarchy into discovering exotic places and thence envisioning their identity, asserting its selfdependency, autonomy, and uniqueness. In this context, Keene seeks to integrate herself into Moroccan life, granting to herself the power to change long-established Moroccan traditions. Specific to this discussion is her assertion that

in the Shareef's lifetime barley was supplied to the animals of notables, but since his death I gradually omitted that, and now only in very extreme cases do I give sufficient for saddle-horses or mules as the case may be. But for the unsolicited offerings, it would be impossible to keep up a custom extending over thirteen hundred years. (Keene 1912, p. 7-8)

Just as more appropriate to this context is the way Keene inserts her uniqueness as an outsider in Morocco, remarking: "No one was permitted to pass in and out the town by way of the Kasbah during the Sultan's residence there, though no objection was raised to my doing so." (Keene 1912, p. 124). In the same way, Keene further demonstrates her access even into sacred places such as mosques and sanctuaries, which is forbidden for non-believers. She, on this subject, exclaims: "No Jew or Christian is permitted to enter the sacred portals, but no objection has ever been raised to my visits."(Keene 1912, p. 135). Still in the same context, Keene tentatively inserts: "I suppose a Moorish mother does not experience the qualms that I did . . I think if I had given the least encouragement to Muley Ali [her son from the Shareef], he would have preferred a European. .." (Keene 1912, p. 147). While emphasizing her uniqueness and superiority to Moorish ladies, Keene also asserts her influence and heroism in that she could have encouraged her son to follow the steps of his father and marry a European. Embedded in this assertion is the threatening tone of power which resonates over her implicit declaration.

In view of the account of her sympathy towards Moroccans in other parts of the text, Emily Keene is also observed to travel not as part of the colonial enterprise but simply as an individual explorer. Her experience with the Moors, their lives, customs, and manners is depicted in such a way as to diminish the possibility of any embedded intention to instil Western agency. In the context of identifying the general character of Moorish ladies, Keene says: "Moorish ladies, in general, are very observant, and their criticisms of visitors are most remarkable, be they sisters or of another nationality." (Keene 1912, p. 51). While this quotation bears a somehow indirect critical tone of the Moroccan tendency to criticize each other, the following is an articulation of the Moorish cleanliness in food preparations:

In their cooking operations the Moors are, as a general rule, extremely cleanly. Meat and poultry are always washed in at least three waters. In bread-making the arms and hands are always washed with soap and water before the dough is mixed, and wheat is generally washed in two waters and dried before being sent to the mill by those who prefer grinding their own wheat to purchasing flour by pound weight or by the sack (Keene 1912, p. 52-53)

Descriptive as it may be, this quotation is an instance of how autobiographical works function to report not only the eventful processes underwent by the author but the whole population's life-styles, manners and traditions.

Additionally, autobiographical works are by no means devoid of instances pointing to the negative side of those traditions. On the same issue of cleanliness, thus, Keene remarks: "The Arabs, both male and female, are uncleanly in appearance; their surroundings compel them to be so, especially when water is, as in so many encampments, some distance from them, and it is as much as the young girls, and sometimes women, can do to carry sufficient for the daily demand."( Keene 1912, p. 89). Keene interprets not only the familiar but also the unfamiliar sights for the reader. In doing so, she often generalizes, simplifies, and, even more problematically, dehumanizes the people she encounters. The following quotation by Keene is a case in point: "The 
Moors do not restrain themselves from making audible guttural sounds after meals, which rather shocks those uninitiated to this rather unpleasant custom" (Keene 1912, p. 41).

\section{Concluding Remarks}

This paper analysed the representation of Morocco by a British female traveller during the late nineteenth and early twentieth century. Emily Keene's travelogue My Life Story was seen to adopt the autobiographical approach, insisting on narrating her life as a non-native female in a strange land, portraying her experience while describing the peculiarities and inferiority of natives in comparison to her homeland. Travel accounts were thus observed to allow their writers a space to construct both a personal identity and a professional and international gendered presence.

Through travel writing and the art of autobiography, the representation of the 'Self' in the context of the 'Other' is seen to be a difficult process because it is mediated by discourses of authority, uniqueness and superiority Thus, the representations in Keene's travel narrative of the constructed 'Self' can bear a variety of interpretations and connotations depending on the historical context of narration through which divergent visions and contradictory attitudes with regard to the issue of Western authority and domination are put into the investigation.

An analysis of this travelogue also shows how its writer was a conscious and an unconscious informant preparing the way for the European colonisation of the country; it is the living witness of an evolution through which culture was forced to open itself to foreign powers. Hence, the traveller's discourse about Morocco contributed directly and indirectly to the consolidation of Western political attitudes towards the country and its subsequent colonisation. At the turn of the twentieth century thus, there was an almost homogeneous discourse on Morocco, if not about the necessity of its colonisation, about its difference and backwardness.

Funding: This research received no external funding

Conflicts of Interest: The author declares no conflict of interest.

Acknowledgement: The author of the current paper would like to acknowledge the valuable contribution of late Professor Abderrazzak Essrhir to this study,especially at the stage of analysing excerpts and writing various drafts that brought the paper to its final shape.

\section{References}

[1] De Beauvoir, S. (1973). The Second Sex. London: Vintage Books.

[2] Foucault, M. (1979). The History of Sexuality. London: Penguin.

[3] Kaplan, C. (1994). The Politics of Location as Transnational Feminist Practice. In Inderpal G. and Kalpan. C (Eds) Scattered Hegemonies. USA: U of Minnesota Press.

[4] ---. (1996). Questions of Travel: Postmodern Discourses of Displacement. USA: Duke UP.

[5] Keene, E. (1912). My Life Story: Emily, Shareefa of Wazan. In S. L. Bensusan (ed). London: Edward Arnold.

[6] Louis Pratt, M. (1985). Scratches on the Face of the Country; or, What Mr. Barrow Saw in the Land of the Bushmen in Critical Inquiry 12. 1 Autumn http://www.journals.uchicago.edu/doi/abs/10.1086/448324

[7] ---. (1994). Imperial Eyes: Travel Writing and Transculturation. London: Routledge.

[8] ---. (1999). Arts of the Contact Zone. In Bartholomae D. and Petroksky A. (Eds) Ways of Reading $5^{\text {th }}$ ed. New York: Bedford/St. Martiss.

[9] c: \Documents \& settings $\backslash A d m i n \backslash M e s$ documents $\backslash$ Arts of the contact zone.htm

[10] Maggio, J. (2007). "Can the Subaltern be Heard ?": Political Theory, Translation, Representation, and Gayatri Chakravorty Spivak". Articles in Oct-Dec 2007, issue of Alternatives: Global, Local, Political. http://findarticles.com/p/articles/mi hb3225/is 4 32/ai n29405601

[11] Mills, S. (1993). Discourses of Difference: an Analysis of Women's Travel Writing and Colonialism. London: Routledge.

[12] Morton, S. (2003). Gayatri Chakravorty Spivak. London: Routledge.

[13] Nelson, G. \& Lawrence G. (1988). Marxism and Interpretations of Culture. Urbana: U of

[14] Illinois $P$.

[15] ---. (1994). "Knowledge, Gender, and Empire". In Blunt A. and Rose G. (Eds) Writing Women and Space. USA: Longman.

[16] Prasad, P. (2005). Crafting Qualitative Research. USA: M. E. Sharpe, Inc.

[17] http://books.google.co.ma/books?id=D26aoqe6bJYC\&printsec=copyright\&dq=gramsci+and +colonial+discourse\&hl=en\#PPA275,M1

[18] Spivak, G. C. (1997). Three Women's Texts and a Critique of Imperialism. Postcolonial Criticism. In Bart-Moore Gilbert, Gareth Stanton, and Willy Maley (Eds). London: Longman.

[19] ---. (1999). A Critic of Postcolonial Reason: Toward a History of the Vanishing Present. London: Harvard UP. 